\title{
BECOMING AND BE/LONGING: KATE BORNSTEIN'S GENDER OUTLAW AND MY GENDER WORKBOOK
}

\author{
BINA TOLEDO FREIWALD
}

The oppression of love, sex, and desire are built into the very nature of the kind of communities in which we huddle. . . . We do all this stuff, I think, because we're so afraid of not belonging, so afraid of being alone.

- My Gender Workbook 93

\section{SUBJECT(IFICAT)ION, BE/LONGING, AUTOBIOGRAPHY}

It is perhaps only fitting that one of the key tenets of autobiography criticism at the dawn of the new millennium - that we become subjects through the workings of a constituting social order within which, however, we can still exercise agency and self-determination-should echo the teachings of the ancients. A Midrashic commentary of the seventh century has it that "a man is called by three names: one given him by his father and mother, one that others call him, and one that he calls himself." ${ }^{1}$ Here are two contemporary autobiographical articulations of this logic of self-naming. "I am neither man nor woman," affirms Michael Hernandez in a short self-portrait included in Leslie Feinberg's TransLiberation: Beyond Pink or Blue, "I just am" (76). And in her Foreword to the collection Boys Like Her: Transfictions, Kate Bornstein reflects on the pain she would have been spared if, as a youngster, she could have simply told the world: “I'm a girl, but I'm a boy, I am" (11). The texts by Hernandez and Bornstein foreground issues of vital interest to contemporary autobiography studies: the "existential necessity" of having a sense of self-of affirming "I am" - and the function of self-narration as a medium of/for such self-creation (Eakin 46); the range of culturally and historically specific "vocabularies of the self" through which subjects are constituted (Bjorklund 7); and the possibility that a subject so constructed 
(here, through a binary gender discourse) may defy and re-define the terms of its naming. These, then, are the broader questions that motivate the present essay. If, as social psychologist George Herbert Mead was already arguing at the turn of the twentieth century, "the human self arises through its ability to take the attitude of the group to which he belongs-because he can talk to himself in terms of the community to which he belongs" (Movements 375; emphasis added), what happens to the self and to self-narration (talking to oneself) when the terms of the community and the group are no longer applicable or acceptable to the self, and belonging is jeopardized? What can non-hegemonic subjects like Hernandez and Bornstein teach us about the interrelationship of subjectivity, belonging, and autobiography?

The contemporary theoretical scene, in which philosophical, sociological, psychological, and textual perspectives have been brought together, provides a fertile ground for such explorations. Drawing out the psychic implications of Foucault's and Althusser's theorizations of the subject as paradoxically constituted by and in subjection, Judith Butler has argued that "no subject emerges without a passionate attachment to those on whom he or she is fundamentally dependent" (7). Since it is the internalization of social norms that produces the subject's "interiority" in the first place, the subject depends on these interpellations to bring it into being and confer upon it a recognizable and enduring social existence. Such attachment, therefore, is both enabling-it is necessary if the subject is "to persist in and as itself" in a "psychic and social sense" - and a mark of subjection-to be, the subject has to submit to "a world of others that is fundamentally not one's own" (Butler 8, 28).

In this essay I would like to suggest that be/longing-the longing to belong so that one may be-is a primary manifestation of the subject's conflicted, passionate attachment to the very grids of affiliation that work in the service of its subject(ificat)ion. Be/longing is the "longing for social existence" of a subject constituted by social categories that signify its "subordination and existence at once" (Butler 20). Not all subjects, however, are equally subjected by the regimes of power that regulate the conditions of their existence. "How do you begin to be/long when everything around you conspires to keep you alien?" asks Marlene Nourbese Philip as she reviews the long history of territorial, social, and psychic dispossession experienced by Africans in the Caribbean and the Americas (22), reminding us that the subject's founding struggle is always already inflected by the particular sociohistorical conditions that shape its lived experience. We "live in time and politics," Carolyn Steedman reaffirms - speaking from the perspective of the classed subject-so that the psychodrama of selfhood will be differently experienced and interpreted by subjects "according to the social circumstances" they find themselves in (111). 
A sexed and gendered subject's fraught becoming and be/longing are at the center of American performance artist Kate Bornstein's Gender Outlaw: On Men, Women, and the Rest of $U s$ (hereafter GO) and My Gender Workbook (hereafter $G W$ ). ${ }^{2}$ Introducing herself as a post-operative male-to-female "transsexual lesbian whose female lover is becoming a man" (GO 3), Bornstein challenges the terms of her subjection, rendering questionable-indeed untenable - the hegemonic grids of sex, gender, and sexuality of a society some have described as founded on "the apartheid of sex" (Rothblatt) and the "tyranny of passing." 3 But having such a fluid sexual/gender identity becomes problematic, Bornstein acknowledges, because the social order can only render it as absence (no self) and otherness (no community): "the need for a recognizable identity, and the need to belong to a group of people with a similar identity . . . are driving forces in our culture, and nowhere is this more evident than in the areas of gender and sexuality" (GO4-5). Bornstein seeks to counter the risks of psychic and social disintegration by renaming herself and redefining her community. Allying herself with those who are "'transgressively gendered' . . . who break the rules, codes, and shackles of gender" ( $G O 135)$, she insists on the right to self-fashioning: "That's how I see myself: I live pretty much without a gender, which paradoxically means I can do many genders" ( $G W 14$ ). Bornstein's narratives, then, engage us in questions central to the contemporary interrogation of subjectivity, agency, and self-narration. They invite us to reflect on the ways in which a subject, risking its continued psychic and social existence, may oppose and transform "the social terms by which it is spawned," thereby (possibly) clearing the way for "a more open, even more ethical, kind of being, one of or for the future" (Butler 29, 130). And they call upon us to develop a critical paradigm committed to examining the relations between lived experience and representation, so that we may not reduce the embodied experience of such a subject "to the figural dimensions and functions of discourse" (Namaste 194). ${ }^{4}$

In form and content, Gender Outlaw is shaped by the objectives that drive Bornstein's autobiographical project: to critique the dominant bi-polar gender system; to explore a different, transgendered, mode of being, in which one will not have to be "one or the other" ( $G O 8)$; and to envision a social space in which a transgendered person could not only become but also belong. Like the identity it seeks to represent, Gender Outlaw is a "cut-andpaste thing" ( $G O 3$ ), a generically hybrid, multivoiced, and dialogic collage that includes personal narrative, theoretical discourse, campy humor, activist polemics, transcripts of interviews and speeches, photographs, the script of Bornstein's play "Hidden: A Gender," and numerous quotations culled from a wide range of sources. I read My Gender Workbook, subtitled "how to become a real man, a real woman, the real you, or something else entirely," as a sequel and companion volume to Gender Outlaw. It is, again, a hybrid 
work that includes "words from over 300 people" (GW Acknowledgments), comic-style illustrations, and the text of "Post Hard: An Online Play in One Act." (More on Bornstein's enthusiasm for cyberspace later.) As its title promises, however, the bulk of My Gender Workbook consists of an impressive array of exercises and activities that Bornstein has designed for her readers to do, so that together-with her, with each other-we could "go on a little journey ... through previously unexplored and underexplored areas of gender, identity, sexuality, and power" (2). Gender Outlaw and My Gender Workbook thus seek not only to trace the emergence of an oppositional subject, but also to enable and facilitate-by evoking the words of others and by direct appeal to the reader-the emergence of an oppositional collectivity and a different manner of belonging.

In Second Skins: The Body Narratives of Transsexuality, Jay Prosser comments on what distinguishes Gender Outlaw- "Our first 'postmodern' transsexual (thus posttransexual) autobiography"-from conventional transsexual autobiographies. Bornstein "doesn't so much narrativize her transsexual life as (a performance artist) she performs it, acting out-without integrating into a singular stable gendered identity-its parts" (174). What I am particularly interested in reflecting on here are the ways in which Gender Outlaw and My Gender Workbook, while flaunting and advocating gender fluidity, are also profoundly concerned with those relations of belonging, however shifting, that are necessary for the material, epistemic, affective, and social survival of the self. The view that the "need to belong . . . is a fundamental human motivation" (Franken 333) has been argued from the standpoints of psychology, philosophy, sociology, and political theory, and is borne out by many autobiographical works. ${ }^{5}$ A poignant moment at the conclusion of bell hooks' memoir Bone Black speaks to this constitutive desire. Recalling a time of great crisis in her life, hooks reveals that what brought her back to life from the edge of loneliness was her grandfather's wise counsel, telling her that "there are lots of ways to belong in this world. And that it is my work to find out where I belong" (182). Not surprisingly, when describing the work of belonging, hooks also articulates what is often the work of autobiography: to conjugate self and other; to create a place to call home; to make oneself at home in the world; to find ways of being at, or when necessary, leaving home-the home that is one's body, the physical, affective, and social spaces inhabited by that body. As members of the Taste This queer collective write in their introduction to Boys Like Her, a volume of personal writings, such stories "are about home, about leaving it and finding it somewhere else" (14). The pressing question for the autobiographical self then, as Janet Varner Gunn has suggested, is "where do I belong? not, who am I?" (23). ${ }^{6}$ 


\section{SELF(ISH) PORTRAITS}

"What transgender identity specifically problematizes," observes Eleanor MacDonald, "is identity itself" (5). To help sketch out a critical context within which to examine Bornstein's interrogation of subjectivity, I would like to draw on the playful musings of the Portuguese dancer-choreographer Joao Fiadeiro. Appearing in Montreal a few years ago, Fiadeiro performed two works, "Is the Self a Portrait?" and "Self(ish) Portrait." In an interview, he described his work as tackling questions like "How me can I be?" (HoweBeck). Fiadeiro's question foregrounds the subject as always already split and different from itself, a post-Althusserian subject who is the site of "multiple solicitations, multiple markings of "identity," but also of "multiple figurations of agency" and resistance (Gilmore 186). Among other things, it is this awareness of self-difference, and the desire for self-belonging it begets, that make the transsexual subject a paradigmatic autobiographical subject. ${ }^{7}$ Bornstein quotes David Harrison (her lover at the time, himself going through female-to-male sex change) who, in response to the question whether the transgendered community is like the lesbian/gay communities, replies: "no, because the lesbian/gay communities are based on who one relates to, whereas the transgendered experience is different: it's about identity-relating to oneself" ( $G O$ 67; emphasis added). Bornstein needs to engage in such selfreflexivity-to engage in the subject-constituting acts of "one who can take oneself as an object" (Butler 22)-because in his/her life, gender assignment has not been naturalized or internalized. As Bornstein writes, "I never did feel like a girl or a woman; rather, it was my unshakable conviction that I was not a boy or a man. It was the absence of a feeling, rather than its presence, that convinced me to change my gender" (GO 24). Such a failure of interpellation creates favorable conditions for a critique of the gender system and the larger project of subject constitution within which it is embedded, and clears a space within which the subject's continuous becoming can unfold.

Fiadeiro's title "Is the Self a Portrait?" further unsettles the assumption that self-representation involves unmediated access to a preexisting, authentic self, suggesting instead that the self is as much producer as end product of representation. In this view, subjectivity is created and sustained through an ongoing, all-pervasive narrative process; as Anthony Giddens puts it, "We are not what we are, but what we make of ourselves" (75). Drawing out the implications of such an understanding for the study of autobiographical narratives, Paul John Eakin has observed that "the selves we display in autobiographies are doubly constructed, not only in the act of writing a life story but also in a lifelong process of identity formation of which the writing is usually a comparatively late phase" (ix). In this respect as well, the transsexual narrative of self is paradigmatic, for it renders visible a process of subject 
construction that in more hegemonic subjects has been naturalized into invisibility. Transsexuality "is always narrative work" (4), Prosser observes, since the

transsexual's capacity to narrativize the embodiment of his/her condition, to tell a coherent story of transsexual experience, is required by the doctors before their authorization of the subject's transition. . . . Narrative is not only the bridge to embodiment but a way of making sense of transition, the link between locations: the transition itself. (9)

This performative and motivated aspect of the autobiographical act is highlighted in Fiadeiro's title "Self(ish) Portrait," which questions the presumed neutrality of self-representation, suggesting instead that it is an act driven by interests and desires, and intended to produce certain effects. Leigh Gilmore captures this idea in the two-word sentence "Identity acts" (238), suggesting both that self-representation is a medium through which identity is fashioned and agency is exercised, and that identities are always on the move, changing and effecting change. It is this aspect of the autobiographical act that interests me here; with theorists like Jerome Bruner, I am less concerned with asking what autobiography "is an interpretation of," and more interested in asking who and what "is it for?" (Kerbrat 33). ${ }^{8}$

It should come as no surprise that the critical literature most responsive to this view of autobiography as performative and motivated has been concerned with embattled subjects whose self-narratives seek to challenge those fictions of race, class, sex, gender, or nation by which an oppressive regime has naturalized its hold over them. Resistance, Foucault has taught us, consists not in discovering what we "really" are, but in refusing what we are presumed to be, so that we may imagine "new forms of subjectivity" (216). This in turn necessitates both a critique of the dominant axes of belonging and a re-imagining of community, for new stories of the self "depend upon communities that will create and hear those stories . . . and these stories work their way into changing lives, communities and cultures" (Plummer 145). The critical project of studying transsexual narratives, then, has precursors in the study of counter-hegemonic practices in women's self-representations, ${ }^{9}$ and in African American autobiography. Feminist scholars and theorists of African American autobiography have made the case for autobiography as a discourse of resistance and counter-interpellation that has functioned as "both an arsenal and a battle ground" in the fight over the self (Butterfield 284). As a liminal subject, Bornstein deploys the autobiographical mode to many of the same ends described by William Andrews in his study of early Afro-American autobiography. Drawing on speech act theory, Andrews examines the illocutionary and perlocutionary dimensions of slave narratives, underscoring what their narrators do in saying certain things, as well as their 
intended effects on the thoughts, feelings, and actions of their audience. ${ }^{10}$ The enactment of agency through autobiography that Andrews describes foregrounds two main operations crucial to Bornstein's transgendered narratives as well. The first is the deployment of the declarative, that is, the speech act that allows one to assume "the prerogative to define [oneself]" while challenging one's audience to reexamine its concepts of "identity and personal value" (Andrews 105, 29). The second involves reconfiguring relations of belonging: both to oneself-for example, by revisioning one's past, or appropriating new models for the self-and in relation to others, by redefining "one's place in the scheme of things" so as to create a community and then affiliate oneself with it (7). ${ }^{11}$ Autobiography thus provides the liminal subject with the means to carve out a counter self-discourse and enact those $\mathrm{w} /$ rites of transition that will take it over the (hegemonic) threshold and into new relations of belonging.

\section{OUTING GENDER}

The problematic belonging of a differently sexed and gendered subject is the dramatic focus of Bornstein's play "Hidden: A Gender," embedded in the autobiographical narrative of Gender Outlaw. One of its characters, the hermaphrodite Herculine Barbin (known to us mostly through Foucault), is brutally forced to choose a sex and a gender, and becomes Abel. Despairing over the many losses this entails, and plagued by a profound sense of unbelonging in the world, Abel can only hope for a homecoming in death: "The incessant struggle . . . exhausts me more each day, and drags me with great strides towards the tomb. . . . There without any doubt the poor wretch exiled from the world, shall at last find a homeland, brothers, friends. And there, too, shall the outlaw find a place" (218). The spatial metaphor here resonates with Bruner's and Weisser's description of the experience of identity as a striving for "self-location," driven by the need to "locate ourselves in the symbolic world of culture" so as to claim a measure of agency (133). When Herculine is forced to become Abel, a monstrous process of dispossession is unleashed, beginning with four leeches inserted deep inside her, "growing fat on the last traces of my womanhood" (188). It is a process that can only end in the subject's demise, for Herculine/Abel becomes an exile in her/his own body and in the world. ${ }^{12}$

By the time the last curtain falls, however, at least one of the play's outlaw characters - Bornstein's namesake Kate- has survived the search for a place of belonging. In the play's penultimate scene, Kate, who used to be Herman (Bornstein's middle birth-name), exits with these words: "I've said my piece, and I feel . . . curiously relieved. You work out the rest, if you have the energy for it. The outlaw has found her place" (222). Bornstein the playwright 
packs much into this parting gesture, which anticipates in a mise en abyme fashion the central concerns of her autobiographical narratives. "I've said my piece," Kate declares, and the piece she just finished saying is

I'm constructing myself to be fluidly gendered now. ... I don't consider myself a man, and quite frequently I doubt that I'm a woman. And you-you still think gender is the issue! Gender is not the issue. Gender is the battlefield. Or the playground. The issue is us versus them. Any us versus any them. One day we may not need that. (222)

There is relief, then, in calling gender's bluff, in exposing the cruel arbitrariness of made-up constructions masquerading as natural law. But there is fatigue, too ("You work out the rest, if you have the energy for it"). Fatigue first because there are all those addressed by Kate's "you" who have yet to see that gender is not the issue, and of course as long as they don't see it, there is going to be much more fighting than playing in the fields of gender. But fatigue too, I think, because if the issue is belonging, it remains far from settled, can perhaps never be settled. Gender, another character in the play suggests, is a symptom of a need-"the need to belong" (195). So that while critique - the free fall off the edge-allows one to recognize gender as a construction, and a mean-spirited one at that, it can do little to satisfy that hunger, the need and the longing to belong. "I feel . . . curiously relieved," Kate says, "The outlaw has found her place." It is in Kate's body that Herman has found a home, but that belonging can only be articulated as a longingin the third, not first, person - and tellingly, through recourse to the very categories of gendered belonging one is questioning. Kate finds her not his place.

\section{REWRITING THE NARRATIVE OF ORIGINS}

From its opening pages, Gender Outlaw revisits and reenacts the interrogation of identity and belonging that drives the play embedded within it. The autobiography opens with two narratives of origin, juxtaposed on opposite pages following the title page. On the left-hand side, there is what looks like the first page of a baby album. It features a picture of the newborn at the bottom of the page, and on top a picture of the proud (and rather formal) mama and papa. (Papa's pipe seems to say it all: Mazel Tov, it's a boy!) Mother is standing behind the seated father, against the backdrop of a mantelpiece on which are displayed (and again reflected in the mirror behind) what look like the iconic objects of a Jewish middle-class household, two Sabbath candles in sparkling crystal holders. A given name and birth date appear on either side of the baby picture, and at the center of the page is the following inscription: "LIFE WITH FATHER AND MOTHER BEGAN FOR ALBERT HERMAN MARCH 15th." Here then is the generic narrative of the self's 
origins, a map of those multiple grids of interpellated belonging that await us upon birth. Released into the world without our consent, we have initially no say over the many factors that will mark our destinies: the gene pool, color of skin, sex, class, and given name-here Albert Herman Bornsteinwith all that's in a name, including a gender (here masculine), and familial and collective history (here Eastern European Jewish).

On the opposite page, at the very top, is another picture of the newborn, this time not alone, but in the arms of the smiling, radiant mother. Papa is gone. Under the picture, a very different inscription, and a narrative of selfbegetting and self-belonging:

I keep trying to integrate my life. I keep trying to make all the pieces into one piece. As a result, my identity becomes my body which becomes my fashion which becomes my writing style. Then I perform what I've written in an effort to integrate my life, and that becomes my identity, after a fashion. (emphasis added)

From the outset, then, Bornstein's figuration of the self as fluid, fragmentary, and multiply coded also includes a longing for a manner of being through which a sense of continuity can coexist alongside plurality and change. There is a double imperative in the identity act that is played out in the two inaugurating narratives of origin. The right to self-difference is claimed, but so too is the ability to say I, me, mine. Kate and baby Albert are different yet the same. Time and genital surgery have altered that body, but
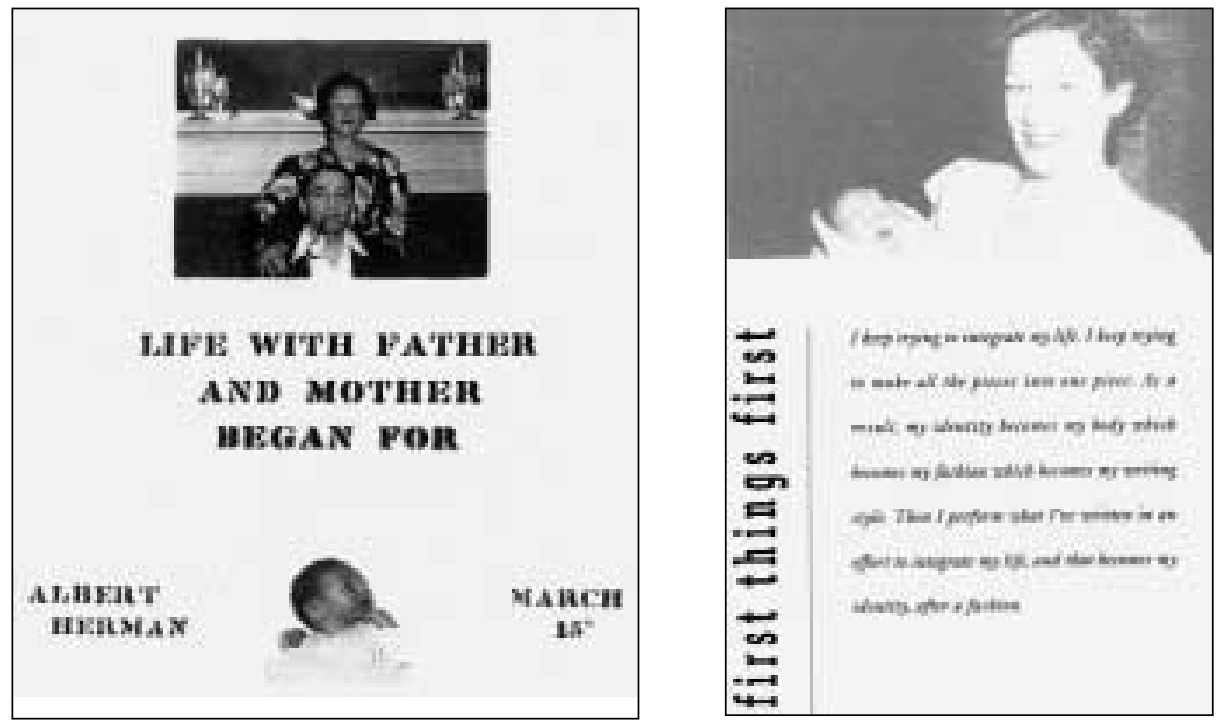

(Photos from Gender Outlaw appear by the kind permission of Kate Bornstein.) 
it is recognizably hers-all the more so, perhaps, because she has taken possession of it, has exercised choice in altering it, ${ }^{13}$ just as she can have an even greater claim to her personal past by exercising choice in relation to kin: in the revised family picture, mother is in, father is out. ${ }^{14}$ But there are things she cannot and would not want to alter. The last chapter of Gender Outlaw, in which Kate takes stock of her seven years of living as a woman, is prefaced by the same baby picture of Albert that opens the book. Albert will always be the baby Kate was, and she won't have it any other way. ${ }^{15}$

As Bornstein points out, the imperative to reclaim a past so as to have a future is particularly problematic for the transsexual subject. ${ }^{16}$ "Transgendered people," and especially post-operative transsexuals, "are not allowed any history beyond their current gender-we're not supposed to reveal our transgender status or our other-gendered past." But "having been male," she writes, is "part of me, and I need my male past as a reference point in my life. Discouraged from examining our past, transgendered people are discouraged from growth" (127). It is this injunction against the autobiographical-the injunction that one relinquish, erase, one's other-gendered self and its past-that Bornstein defies by writing Gender Outlaw. And the stakes could not be higher, for it is her survival as a subject that is on the line: "silence does equal death" (94). Through the agency of self narration, in which retrospection enables projection, she gathers in and reassembles herself by remembering. Remembering the thirteen-year-old Bar-Mitzvah boy who was instructed to pronounce "Today I am a man" (20). Remembering the man who by the age of thirty had tried just about every avenue of escape: "I hid out in textbooks, pulp fiction ... drugs and alcohol. I numbed my mind with everything from peyote to Scientology. I buried my head in the sands of television, college, a lot of lovers, and three marriages" (59). Remembering, too, the shame, as a transsexual woman, at failures to pass. But what the pieces yield is greater than the sum of their parts. The lessons learned open up new avenues of critique and of self-fashioning, as Bornstein arrives at a non-essentialist view of identity, one that allies subjectivity with change and with choice: "I'm not under any illusion that I am a woman. ... And I'm not under the illusion that I am a lesbian. It's the difference between being an identity and having an identity. The latter makes more room for individual growth" (243). Challenging the coercive conformity of the demand to "pass," Bornstein claims an "in-between place" where a subject can exist outside the borders of the socially sanctioned (94).

\section{I/MAGIN(IN)G MORE ${ }^{17}$}

One of the ways in which Bornstein re-presents the story of a subject who has transgressed and survived to tell a different tale is through the incorporation 
of photographic self-images into the textual narrative of Gender Outlaw. To some readers, the photographs appear to undermine Bornstein's vision of living without gender and outside the self-identifications of "man" and "woman." Pat Califia points out that the images of Bornstein as a child and an actor make her look male, while the author's photo is "not readable as anything other than the image of a beautiful, feminine woman" (259). What Califia's brief discussion fails to account for, however, is Bornstein's strategic deployment of visual self-representation as a dynamic element in her unfolding narrative of self. As Timothy Dow Adams has demonstrated, autobiographical "texts and images can interact with and reflect on each other," both modes of self-representation blurring "the boundaries between fact and fiction, between representation and creation" to better serve the project of self-fashioning (xxi, 20). The photographs in Gender Outlaw have to be read not only as they form an embedded visual narrative in dialogue with the larger textual narrative, but also as they are interpreted and transformed by the captions that accompany and indeed complete them. Thus, Bornstein's "feminine" image on the front cover of Gender Outlaw: On Men, Women, and the Rest of $U$ s-legs apart and arms crossed over her chest, in a black dress, ankle-high lace-up boots, loop earrings, eyes inviting/challenging, lipsticked mouth slightly open-is made to signify differently by the book's playful gender-bending title inscribed over it. Both this image and the next one, which appears opposite the title page-Bornstein seated in the same outfit, legs crossed to show some skin, her chin resting on one hand, the other placed suggestively on her bare knee, smiling at us teasinglyinvite us to contemplate, but also enjoy, the spectacle of gender. In these opening images of Bornstein at the present time of narration, she appears happy and playful - happy indeed because she can, finally, be playful.

Things were not always so. The next two images in the book offer the juxtaposed narratives of origin discussed earlier. In the first, the solemn parents appear to be overseeing baby Albert Herman's initiation into a world governed by the forbidding Law-of-the-Father. In the second, the mother's radiant smile welcomes the infant into the world of jouissance and play. On the following page, the same picture of mother and baby is reproduced, now with the caption: "My mother was so proud to have given birth to a son. Today, our friendship is more than either mother-son or mother-daughter" (2; emphasis added). Play provides Bornstein with a model for having/being more, and so performance becomes both the practice of and trope for her becoming. But the world around the young, and then adult Bornstein would prove to be far from playful. Opposite the first page of "The Hard Part," chapter two of Gender Outlaw, is a picture of Bornstein as a four-year-old, "in the backyard of our house on the Jersey Shore" (6). It is an image of a child alone, holding onto a wire fence that forms a cage-like grid against and 


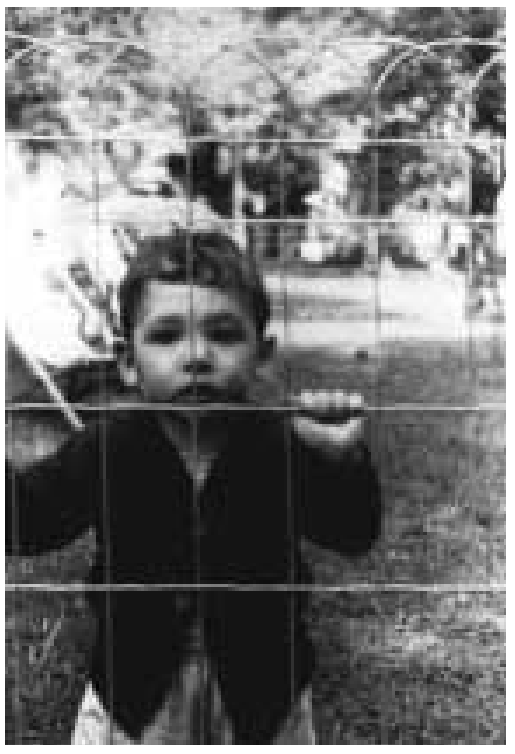

In the backyard of our house on the Jersey Shore. I'm about four years old.

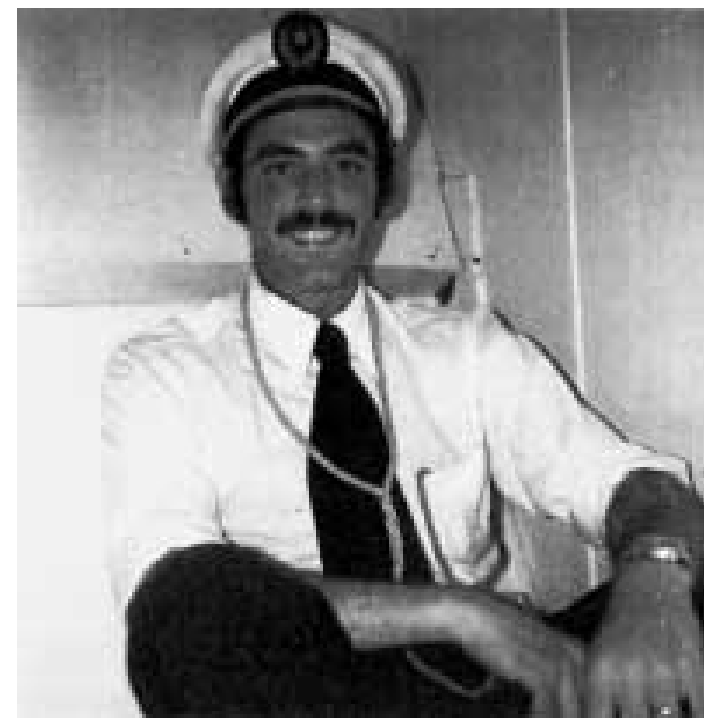

Warrant Officer Al Bornstein, First Mate aboard the sea-going yacht Apollo, flagship of the Church of Scientology.

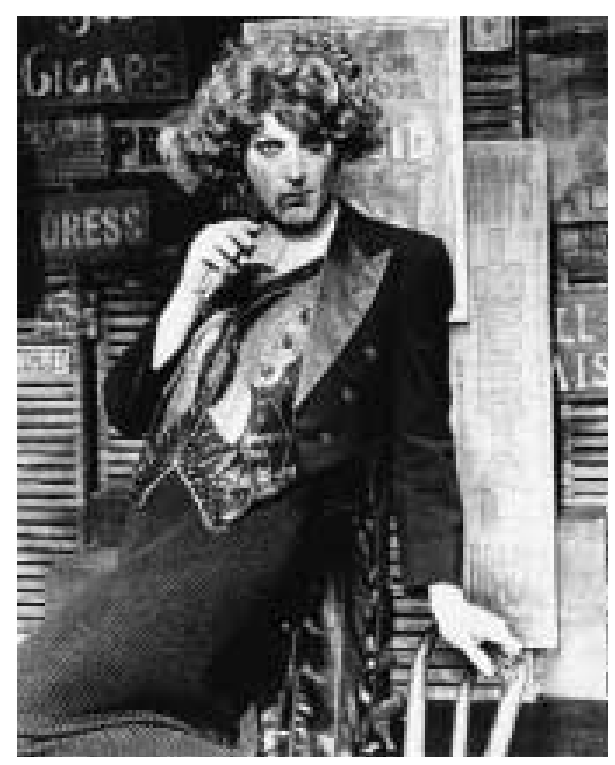

The Fly, the leader of a gang of criminals in the Wilma Theater production of the Brecht/Weill musical, Happy End, 1987, in Philadelphia, directed by Jiri Ziska. It was my first role in women's clothing, and I doubled as the male master of ceremonies.

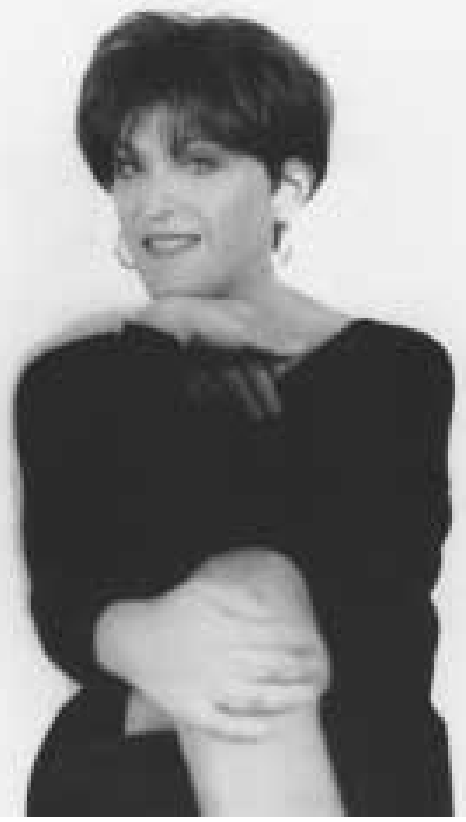

(Photos from Gender Outlaw appear by the kind permission of Kate Bornstein.) 
around its body - a body caught in the grid of interpellations - a child both locked in and locked out, its sad gaze fixed elsewhere, beyond us and the camera's range. The images strategically placed throughout the book will tell the story of this child's search for the playground denied him/her by the Law of Gender. All the world is a stage indeed-"Everyone is passing; some have an easier job of it than others" (125)—but the Law's power lies in masking the arbitrariness and calculated logic of its founding representations. The ubiquitous nature of these prescriptive scripts is captured by the next photograph, "My Bar Mitzvah: March 4, 1961, 'Today I am a man”" (20). The hold of this gender(ing) role is so powerful, Bornstein notes in the lines immediately following the photograph, that "For the first thirty-or-so years of my life, I didn't listen, I didn't ask questions, I didn't talk, I didn't deal with gender-I avoided the dilemma as best I could" (21). Two more photographs follow: "Asbury Park Public School photo, about ten years old" (44), and "At home in New Jersey, age 13 or 14. I'd already learned to smile for a camera, no matter what was going on" (52). Both photos show the young Bornstein staying 'in character' as a boy and young (male) adolescent.

A way out of this unhappy impasse, however, will suggest itself. The photograph of the adolescent Bornstein smiling for the camera, and the two photographs immediately following, form a mini-narrative that tells the story of this trajectory. At the top of the next page appears an image (produced more fully, with an explanatory caption, a few pages later) of the adult Bornstein in her first role in women's clothing. Underneath, vertically on the left, is the section title "claiming power." Horizontally this text appears: "I learned from working in the Women's movement that one of the first steps in claiming power is to speak one's own voice: to name oneself. Having sorted out the culture's ideas of gender and sexuality, it's time to name the experience of stepping outside those ideas" (53). The image on the following page, as the caption explains, shows the young Bornstein as Launcelot Gobbo, the clown in Shakespeare's The Merchant of Venice (54).${ }^{18}$ Theater, performance, acting, then, may have initially served as no more than avenues of escape from the tyranny of the hegemonic, but they eventually become for Bornstein the very medium of subversion, resistance, and self-creation. The lessons of the theater are vital: that one can step in and out of (gendered and other) roles; that in becoming the other, one may better learn to be/come oneself; and that choice may be exercised in naming one's kin, one's ancestry, one's role models.

Photographs in transsexual autobiography have served both to document a changing body and affirm the existence of a "continuous identity in that very place of alterity" (Prosser 213). They are a way of dramatizing "the individual's communication between his inner and outer self" (Allen 315), and contribute to the creation of a personal as well as a collective archive of 
transgender identity. In Gender Outlaw the photographs do that and more, serving Bornstein's overall project of rethinking identity through autobiography. Thus, within the context of the gallery of roles the photographs represent, the alluring 'femme' of the author's photo becomes yet another role Bornstein has chosen to inhabit, alongside Shakespearean clown, Lear, or the Marquis de Sade (86). This does not trivialize the needs and realities that motivate her sex/gender change, only highlights the constructedness and rigidity of a regime that passes for natural. Similarly, the juxtaposition on facing pages of male- and female-looking photographs of Bornstein (52-53, 140-41) serves both to claim a male-bodied history for the transwoman Bornstein has become, and to defamiliarize either gender representation. In this context, to cite another example, the photograph of the handsome "Warrant Officer Al Bornstein, First Mate aboard the sea-going yacht Apollo, flagship of the Church of Scientology" (100), signifies not the 'normal' congruence of biological sex and gender, but the extent to which normative gender is always already (more or less conscious) passing.

Most of the images in the concluding sections of Gender Outlaw are from Bornstein's work in queer theater. These images provide an appropriate formal and thematic closure to the book, bringing the overall linear visual narrative up to the present, and grounding Bornstein in her chosen space of becoming and belonging. Bornstein's photographic self-narrative, and the text within which it is embedded, thus suggest not a Freudian view of memory as the foundation of identity, and autobiography as the search for the past that has made us what we are, but a more Foucauldian understanding that "fathoming the past teaches us ... that there are options among which we are free to choose, not simply continuities to which we must adapt" (Hutton 139).

\section{GROUNDING}

Three topoi animate Bornstein's autobiographical project, and they can be conceptualized as extensions of the three mind-body exercises she recommends as warm-up before any of the strenuous identity-bending work in $M y$ Gender Workbook: "relaxation, grounding, and protection" (GW226). Relaxation involves an awareness and critique of the gender system so that one may "break free of gender" and let go of a kind of belonging that is predicated on possession and exclusion ( $G O 125)$. Bornstein sees in S/M an enabling practice in this respect:

S/M partners play at what the culture often refuses to acknowledge about itselfowning or belonging to one other. This game highlights factors basic to power: the need to belong, and its two corollaries: the need to own and the need to exclude. ... The fear and hatred of gender outlaws and S/M players is the fear and hatred of those who do not belong, who aren't owned. (GO 125) 
While Bornstein is critical of what our culture tells us- "that we are what we belong to" ( $G O$ 125) - her pursuit of a different kind of belonging is an acknowledgment of what she herself identifies as a "basic drive": a "connection with others," the desire "to be a member of a community" ( $G W 66, G O$ 69). As Bornstein knows all too well, the in-between place of the gender outlaw is not only a place of "horrible loneliness," but also a place bereft of any potential for collective agency and social transformation (GW 66). Gender Outlaw is thus written as much in defiance of a coercive system of gender that conflates being with having, as it is a call for the grounding of the self in a different kind of belonging, one not premised on the need to own and to exclude. Throughout Gender Outlaw: On Men, Women, and the Rest of Us, Bornstein insists "My voice is ... not representative of all transgendered people" (14), but she also insists on the prerogative to say "us"—already signaled by her title-the prerogative to say "our," to say "my people" (84).

For Bornstein, then, the psychic and material protection that a community of belonging offers-in reassuring one that "someplace will always be home" (GW 67) - is always in tension with "the principle of constant change" she upholds as primary ( $G O 69$ ). She acknowledges "there's always a tug" ( $G W 67)$, and traces of this ambivalence are everywhere in Gender Outlaw and My Gender Workbook. Speaking for example of a community she embraces, that of queer theater, Bornstein paradoxically defines it in terms antithetical to the very idea of community, suggesting that in the same way that "a fool and a shaman must, for their continued survival, stay free of attachment to any community, so must [queer] theater stay free of any attachment to a community" ( $G O$ 158). And while she makes the case against any theater "that grows up in a community, with the aim of supporting that community," arguing that it will inevitably seek to pacify its audience and promote the status quo, she also speaks passionately, longingly, not only of the importance of alliances in working towards a common social goal, but also of the vital need for a sense of home and kinship with others. Remembering fondly the first International Lesbian and Gay Theater Conference and Festival, where her play "Hidden: A Gender" was first shown, Bornstein observes that a "number of queer theater artists expressed the feeling that the conference was 'home.' That they'd met their own kind. That it was family" ( $G O 159)$. Other transgendered writers concur: it is in the company of "one's own kind" that one can find "affirmation, healing, and self-definition” (Blumenstein et al. 427).

\section{VII. "together, We could make it A ReAlity" (Feinberg 1)}

Ultimately, however, it is in interrogating and re-imagining who "one's own kind" are that Bornstein and other transgender activists find the answer to 
the conflict between the desire for recognition and belonging, and the rejection of a fixed identity on which such collective identifications could be based. In the recent transgender writings of Bornstein, Leslie Feinberg, and Jason Cromwell, among others, and in the discourses that have emerged out of support groups and initiatives like the New York Lesbian and Gay Community Service Center's Gender Identity Project, the familiar tropes of the quest for identity and the journey home are revisioned and redeployed. They now point not to fixed destinations and self-same identities, but to the creation of material and discursive spaces of solidarity and alliance where subjects could come together to better counter "discrimination and prejudice without guilt, fear, or shame" (Blumenstein et al. 429). It is a position Feinberg puts forward eloquently in TransLiberation. "As alluring as the notion of 'belonging' can be on a hard day," Feinberg tells the True Spirit Conference workshop on transgender, "we don't want to give up the basis of our insights, of our consciousness" (69). Speaking alternately in the first person singular and plural, Feinberg seeks not to renounce belonging but to announce and celebrate a different manner of being in community: "It's been a long, arduous journey. But we found each other. You are home now" (73). Autobiographies, oppositional narratives remind us, are about the remaking of self and home. For non-hegemonic subjects, moreover, autobiography has to function not only as "a mode in which the self or selves are made ready for the future" (Marcus 293), but also as a means by which the future can be made ready for the self.

If Gender Outlaw enacts the becoming of a different subject, its sequel, My Gender Workbook, sets out to help make a future in which such a self can be at home. This in turn can only be accomplished with the help of "you"that is, us. My Gender Workbook, with its gender-bending exercises which are "less about what you already are, and more about whatever you could be" (73), invites the reader to complete the autobiographical act by asking 'Who would I like to become?' Bornstein coaxes us: 'I wrote this book to be written in, okay?" ( $G W 12)$. Theorists of autobiography have commented on the potential of the genre to engender in its readers autobiographical self-reflection. ${ }^{19}$ Drawing on this potential, My Gender Workbook explicitly revises the autobiographical pact by creating a text that both offers Bornstein's autobiographical discourse and demands/elicits the reader's own self-narration. Here, as in other liminal narratives, the appeal to the reader is not incidental, but central to the autobiographer's project of becoming and belonging. Bornstein's vision of the kind of community to which she would like to belong - a community "based less on some notion of a transgender identity, and more on the idea of a transgender value" (GW 257; emphasis added) can only come about through the potentially transformative power of her readers" own self-explorations. What this transgender value might be is "a 
matter to be hashed out by all of us," which would include "anyone who wants to overcome gender oppression in any shape or form" ( $G W 257$ ). Bornstein's autobiographical narratives offer her own contribution to this ongoing conversation about strategies for resisting the hegemonic sex/gender regime. ${ }^{20}$ The future of gender, Bornstein believes, is already here, alive and thriving within what she calls our virtual realities: "the written world, the telephone, electronic bulletin boards, and the great, grand ancestor of all virtual realities, theater" (GO 138). What these spaces allow is joyful "splattering"- the resisting subject's response to the hegemonic injunction to "be" in a self-identical sense. Performing is "an instant splatter into the harmonious and simultaneous expression of all the different aspects of me, denying myself nothing" ( $G W 180)$. As a model for be/longing, "splattering" calls for communities based not on similar identities, but on contiguous interests and common struggles.

"At last I am not alone," bell hooks writes, "I have been seen" (182). In Gender Outlaw Bornstein asks us to see her as she fashions an identity that challenges some of our most entrenched notions. In My Gender Workbook she invites us to reexamine and rewrite ourselves - the book's inside cover bears the inscription: "My Name is ___ and this is MY Gender Workbook" - so that having seen ourselves, we might consider joining her on the catwalk. $^{21}$

\section{NOTES}

1. Bialik and Ravnitzky 683 (my translation from the Hebrew). This midrash is from Midrash Kohelet (Ecclesiastes) Rabbah 7, and Midrash Tanhuma Veyikhal.

2. Elsewhere Bornstein has written about other early experiences of exclusion: as "a preteen who's been laughed at and left out for his weight and his brains and his clumsiness and his Jewishness" (Foreword 10).

3. C. Williams, TGIC Newsletter (Albany, NY, 1985), qtd. in Boswell 57.

4. This is a recurrent concern in the literature on transgender: that the experience of actual embodied subjects not be erased in the rush to appropriate the figures of genderbending for various deconstructive and postmodern projects. The need to hold on to some notion of the specificity of individual subjects-as embodied, as capable of agency in the face of particular material and ideological circumstances, and so on-is expressed by other theorists as well. Paul Smith insists on acknowledging the "subject/individual" (xxxv); Jessica Benjamin maintains that we must "retain some notion of the subject as a self, a historical being" (13); Paul John Eakin chooses to use "self [connoting an embodied selfhood] when dealing with the representation of subjectivity in autobiography" (10). Mead addressed this issue by making the distinction between "me," that aspect of the self that is "constituted by the social relations" and the conventions of the collectivity, and "I," the agential aspect of the self capable not only of responding to "the attitude of the community" but also changing it (Mind 213, 196). 
5. I can only gesture here towards some of the perspectives from which a discussion of the centrality of belonging to subjectivity and agency can be broached. In general, belonging emerges as an imperative in any theory that views the subject as formed in and through relation(s). Paradigmatic in this respect is the linguist Emile Benveniste's formulation that one accedes to subjectivity through a dialogue (which takes place in language) with an other: "Consciousness of self is only possible if it is experienced by contrast. I use $I$ when I am speaking to someone who will be you in my address. It is this condition of dialogue that is constitutive of person, for it implies that reciprocally I becomes you in the address of the one who in his turn designates himself as I"(224-25). Be/longing could thus be conceptualized as the longing for that shared space of reciprocity that alone can confer/confirm the subject's being.

The view that reciprocal recognition is necessary for subjectivity and agency to be fully exercised is central to a range of contemporary theorizations, from the psychoanalytic model of "mutual recognition" and intersubjectivity developed by Jessica Benjamin (33), to the "politics of recognition" argued by philosopher Charles Taylor. These theorizations reject the easy dichotomy of self/other, showing instead that subjectivity and agency emerge out of the productive tension between autonomy and dependency (Benjamin), between what Taylor calls an individualist "politics of equal dignity" and a collectivist "politics of difference" (39). As Michael Ignatieff explains: "belonging also means being recognized and being understood. As Isaiah Berlin has written in Two Concepts of Liberty, when I am among my own people, 'they understand me, as I understand them; and this understanding creates within me a sense of being somebody in the world"' (10; emphasis added). Anthropologist Anthony Cohen echoes this understanding of being-in-belonging, arguing that belonging is that which "binds members to their culture so closely that they take from it the means by which to make the world known to themselves, and to make themselves known to the world" (11-12). Cohen theorizes a continuum of belonging in which the immediate and local structures of belonging-family, friendship, neighborhood, sect-mediate the wider circles of collective and national belonging. In a different idiom but equally emphatic about the role of belonging in the constitution of the subject, psychologist Abraham Maslow placed the need to belong in the middle of a hierarchy of needs- "above physiological and safety needs and below esteem and self-actualization needs" (Franken 332)_-in which higher needs cannot be satisfied unless lower ones have been met.

Recent scholarship on autobiography, by Eakin and Egan among others, has foregrounded selfhood as relational and explored the writing of relational lives.

6. Gunn views autobiography as embodying not the story of Narcissus (who grasped for his "mirror image and drowned in certainty") but that of Antaeus: "As long as this mythical giant remained in contact with earth, his mother, he remained invincible. Antaeus was finally killed by Hercules who, learning his secret, suspended him in the air" (23). The self's identity thus becomes the question of the self's location in the world.

7. In L'écriture de soi, Marie-Claire Kerbrat articulates the logic of this autobiographical imperative: "Je me demande qui je suis, donc j'écris. Je doute (d'être quelqu'un de bien défini), donc je suis." [I ask myself who I am, therefore I write; I doubt (that I am a welldefined being), therefore I am] (134). The experience of the self as multiply interpellated, and the consequent desire for self-belonging, are evocatively captured by Canadian poet Dorothy Livesay in her memoir Journey with My Selves: "The greatest thing in the world is to know how to belong to ourselves" (15). 
8. Kerbrat devotes an aptly titled chapter to these questions: "L'autobiographie: pour qui, pour quoi? Destinataires et destinations de l'autobiographie” [Autobiography: For whom? For what? The Addressees and Ends of Autobiography]. See also Bjorklund's chapter "Autobiography as a Social Situation" (16-42).

9. Central to feminist readings of women's autobiography has been the argument that "alienation from the historically imposed image of the self is what moves the writing, the creation of an alternate self in the autobiographical act" (Friedman 41).

10. By drawing on speech act theory Andrews seeks to avoid an essentializing and mimetic view of self-narration. He approaches self-representation as "a complex of linguistic acts in a discursive field" rather than as "the verbal emblem of an essential self" (23).

11. Kenneth Mostern's recent Autobiography and Black Identity Politics reiterates the centrality to black autobiography and to black autobiography studies of the individual subject's relation to community and the negotiation of collective identities_or as Mostern puts it, "the construction of a 'we"” (50).

12. For a more uplifting and contemporary life-story of an hermaphrodite who has prevailed, see Harris.

13. One of the most memorable lines in Spanish director Pedro Almodóvar's film Todo Sobre Mi Madre [Everything about My Mother] comes from a male-to-female transgendered character called La Agrado. Giving an abbreviated version of her life story, La Agrado runs through the list of plastic surgeries undergone and body parts acquired, complete with price tags. She concludes "You are more authentic the more you resemble what you've dreamed you are."

14. In her Foreword to the collection Boys Like Her, Bornstein tells a revealing family story of the kind conspicuously absent from Gender Outlaw and My Gender Workbook. One day at a restaurant, her father, "a big man, a rude man, a rough doctor of the community," turned to his wife, and clearly distancing himself from the ten-year-old Bornstein, said: "Mildred, your son has eyelashes like a girl" (9). The mother's response, however well intentioned, did little to alleviate her son's pain: "my mother turned to my father there in the restaurant and she said, 'Don't talk like that, Paul, please. It's difficult enough with his weight problem'” (10). For Bornstein, this injunction not to talk (like that) has been at the root of so much suffering. If only, she imagines, that boy with the girly lashes could have said "'I'm a girl, but I'm a boy, I am"”- "What a joy!" (11).

15. As the text accompanying the baby picture here further suggests - it speaks of the recent sea-change in Bornstein's life as her female lover has become her boyfriend, and everything got "thrown back into the blender" (225) — the baby picture also serves as a reminder of the ever-present possibility of remaking oneself. We've all had to do it once: why not again, and again?

16. Jason Cromwell echoes many others in identifying this key issue: "The medico-psychological literature and practitioners and, in the early days, other transpeople told us that we must give up our past" (5).

17. I would like to thank Sidonie Smith for an exchange at the Changing Identities Conference that prompted me to think more about the interface between textual and visual self-representations in Gender Outlaw. Other papers at the conference, including the plenary talk by Sidonie Smith and Julia Watson, offered further inspiration.

18. An image a few pages later shows Bornstein as King Lear. Its caption, "I'd like to do more Shakespeare-the women, or maybe the men" (112), reminds us that the stage 
has a long history of foregrounding not only the representation of gender, but also gender as representation.

19. James Olney has described the reader of autobiography as a "vicarious or a closet autobiographer" (26), and Nancy K. Miller claims that at least some autobiographies "engender the coming to writing" in their readers (135).

20. This conversation is about articulating new paradigms for what Plummer has called "intimate citizenship": that sphere of collective experience that touches on the body, relationships, and sexuality (151). Not surprisingly, new vocabularies are being formed to forge new communities of discourse. "We are all works in progress," Feinberg contends, proposing the use of more flexible, gender-neutral pronouns to accommodate such changes_- "sie" for she/he, and "hir" for his/her (1). Richard Ekins develops a vocabulary that seeks to describe sexed/gendered identity as being in flux over the life span of an individual, identifying a range of modalities of male femaling that respects "the ambiguous, ambivalent, multi-contextual, multi-dimensional, emergent nature of much cross-dressing and sex-changing phenomena" (2). At one end of such a continuum is a self-described "'gender transient' - a person who puts their gender in transience in order both to study it and to live a life which maximally integrates the masculine and feminine in one's personality" (154). Another way of conceiving of the cross-gender experience is as a non-pathological "multiple personality order," in which individuals do not experience temporary amnesia or feel "unreal" in their alternate personality experience (Henkin 169).

21. The spirit of this invitation was nicely captured by the cover of the September-October 1998 issue of the Utne Reader, which also included a short contribution by Bornstein. On the cover, next to an image of an ambiguously gendered couple (body hair is showing through 'her' dress, female breasts are visible through 'his' jacket), the caption reads: "It's 2 a.m. Do you know what sex you are? Does anybody?"

\section{WORKS CITED}

Adams, Timothy Dow. Light Writing and Life Writing: Photography in Autobiography. Chapel Hill: U of North Carolina P, 2000.

Allen, Mariette Pathy. "The Changing Face of the Transgender Community." Bullough et al. 311-15.

Almodóvar, Pedro, dir. Todo Sobre Mi Madre [Everything about My Mother]. Culver City, CA: Columbia TriStar/Sony/El Deseo/Renn/France 2, 1999.

Andrews, William L. To Tell a Free Story: The First Century of Afro-American Autobiography 1760-1865. Urbana: U of Illinois P, 1986.

Benjamin, Jessica. Like Subjects, Love Objects: Essays on Recognition and Sexual Difference. New Haven: Yale UP, 1995.

Benveniste, Emile. Problems in General Linguistics. Trans. Mary Elizabeth Meek. Coral Gables: U of Miami P, 1971.

Bialik, Haim Nahman, and Yeoshua Hana Ravnitzky, eds. Sefer Ha-Aggadah. Tel Aviv: Dvir, 1960.

Bjorklund, Diane. Interpreting the Self: Two Hundred Years of American Autobiography. Chicago: U of Chicago P, 1998. 
Blumenstein, Rosalyne, Barbara E. Warren, and Lynn E. Walker. “Appendix: The Empowerment of a Community." Denny 427-30.

Bornstein, Kate. Foreword. Taste This 9-12.

Gender Outlaw: Of Men, Women, and the Rest of Us. New York: Vintage, 1995.

My Gender Workbook. New York: Routledge, 1998.

Boswell, Holly. "The Transgender Paradigm Shift Toward Free Expression.” Denny 55-61.

Bruner, Jerome, and Susan Weisser. "The Invention of Self: Autobiography and Its Forms." Literacy and Orality. Ed. David R. Olson and Nancy Torrance. Cambridge: Cambridge UP, 1991. 129-48.

Bullough, Bonnie, Vern L. Bullough, and James Elias. Gender Blending. Amherst: Prometheus, 1997.

Butler, Judith. The Psychic Life of Power: Theories in Subjection. Stanford: Stanford UP, 1997. Butterfield, Stephen. Black Autobiography in America. Amherst: U of Massachusetts P, 1974. Califia, Pat. Sex Changes: The Politics of Transgenderism. San Francisco: Cleis, 1997.

Cohen, Anthony P. "Belonging: The Experience of Culture." Belonging: Identity and Social Organization in British Rural Cultures. Ed. Cohen. St. Johns: Memorial University of Newfoundland, Institute of Social and Economic Research, Social and Economic Papers No. 11, 1982. 1-17.

Cromwell, Jason. Transmen and FTMs: Identities, Bodies, Genders, and Sexualities. Urbana: U of Illinois P, 1999.

Denny, Dallas, ed. Current Concepts in Transgender Identity. New York: Garland, 1998.

Eakin, Paul John. How Our Lives Become Stories: Making Selves. Ithaca: Cornell UP, 1999.

Egan, Susanna. Mirror Talk: Genres of Crisis in Contemporary Autobiography. Chapel Hill: U of North Carolina P, 1999.

Ekins, Richard. Male Femaling: A Grounded Theory Approach to Cross-Dressing and SexChanging. London: Routledge, 1997.

Feinberg, Leslie. TransLiberation: Beyond Pink or Blue. Boston: Beacon, 1998.

Foucault, Michel. "The Subject and Power." Michel Foucault: Beyond Structuralism and Hermeneutics. Ed. Hubert L. Dreyfus and Paul Rabinow. Chicago: U of Chicago P, 1982.

Franken, Robert E. Human Motivation. 4th ed. Pacific Grove, CA: Brooks/Cole, 1998.

Friedman, Susan Stanford. "Women's Autobiographical Selves: Theory and Practice." The Private Self: Theory and Practice of Women's Autobiographical Writings. Ed. Shari Benstock. Chapel Hill: U of North Carolina P, 1988. 34-61.

Giddens, Anthony. Modernity and Self-Identity: Self and Society in the Late Modern Age. Stanford: Stanford UP, 1991.

Gilmore, Leigh. Autobiographics: A Feminist Theory of Women's Self-Representation. Ithaca: Cornell UP, 1994.

Gunn, Janet Varner. Autobiography: Toward a Poetics of Experience. Philadelphia: U of Pennsylvania P, 1982.

Harris, Lynn Edward. “A Legal Path of Androgyny.” Bullough et al. 503-504.

Henkin, William A. "Multiple Personality Order: An Alternate Paradigm for Understanding Cross-Gender Experience." Denny 163-79.

Hernandez, Michael. "Portrait: I am neither man nor woman.” Feinberg 74-76. 
hooks, bell. Bone Black: Memories of Girlhood. New York: Henry Holt, 1996.

Howe-Beck, Linde. "Searching for a Sense of Self." Montreal Gazette 2 Oct. 1997: C7.

Hutton, Patrick H. "Foucault, Freud, and the Technologies of the Self." Technologies of the Self: A Seminar with Michel Foucault. Ed. Luther H. Martin, Huck Gutman, Patrick H. Hutton. Amherst: U of Massachusetts P, 1988. 121-44.

Ignatieff, Michael. Blood and Belonging: Journeys into the New Nationalism. New York: Farrar, Straus \& Giroux, 1993.

Kerbrat, Marie-Claire. Leçon littéraire sur l'écriture de soi. Paris: PU de France, 1996.

Livesay, Dorothy. Journey with My Selves: A Memoir 1909-1963. Vancouver: Douglas \& McIntyre, 1991.

MacDonald, Eleanor. "Critical Identities: Rethinking Feminism Through Transgender Politics." Atlantis 23.1 (Fall/Winter 1998): 3-12.

Marcus, Laura. Auto/biographical Discourses: Theory, Criticism, Practice. Manchester: Manchester UP, 1993.

Mead, George Herbert. Mind, Self, and Society. Chicago: U of Chicago P, 1934.

Movements of Thought in the Nineteenth Century. Ed. Merritt H. Moore. Chicago: U of Chicago P, 1936.

Miller, Nancy K. Getting Personal: Feminist Occasions and Other Autobiographical Acts. London: Routledge, 1991.

Mostern, Kenneth. Autobiography and Black Identity Politics: Racialization in TwentiethCentury America. Cambridge: Cambridge UP, 1999.

Namaste, Ki. “'Tragic Misreadings': Queer Theory's Erasure of Transgender Subjectivity.” Queer Studies: A Lesbian, Gay, Bisexual and Transgender Anthology. Ed. Brett Beemyn and Mickey Eliason. New York: New York UP, 1996. 183-203.

Olney, James. "Autobiography and the Cultural Moment." Autobiography: Essays Theoretical and Critical. Ed. Olney. Princeton: Princeton UP, 1980. 3-27.

Philip, Marlene Nourbese. Frontiers: Essays and Writings on Racism and Culture. Stratford, Ontario: Mercury, 1992.

Plummer, Ken. Telling Sexual Stories: Power, Change and Social Worlds. New York: Routledge, 1995.

Prosser, Jay. Second Skins: The Body Narratives of Transsexuality. New York: Columbia UP, 1998.

Rothblatt, Martine Aliana. The Apartheid of Sex: A Manifesto on the Freedom of Gender. New York: Crown, 1995.

Smith, Paul. Discerning The Subject. Minneapolis: U of Minnesota P, 1988.

Smith, Sidonie, and Julia Watson. "Women as Artists and Subjects in Visual and Performance Media." Plenary Address. Autobiography and Changing Identities Conference. University of British Columbia. Vancouver. 27 July 2000.

Steedman, Carolyn Kay. Landscape for a Good Woman: A Story of Two Lives. New Brunswick: Rutgers UP, 1987.

Taste This (Anna Camilleri, Ivan E. Coyote, Zoe Eakle, Lyndell Montgomery). Boys Like Her: Transfictions. Vancouver: Press Gang, 1998.

Taylor, Charles. Multiculturalism and "The Politics of Recognition." With commentary by Amy Gutman (editor), Steven C. Rockefeller, Michael Walzer, and Susan Wolf. Princeton: Princeton UP, 1992. 